\title{
A transcriptome-based model of central memory CD4 T cell death in HIV infection
}

\author{
Gustavo Olvera-García', Tania Aguilar-García', Fany Gutiérrez-Jasso', Iván Imaz-Rosshandler², \\ Claudia Rangel-Escareño ${ }^{2}$, Lorena Orozco ${ }^{3}$, Irma Aguilar-Delfín ${ }^{3}$, Joel A. Vázquez-Pérez ${ }^{4}$, Joaquín Zúñiga ${ }^{1}$, \\ Santiago Pérez-Patrigeon ${ }^{5}$ and Enrique Espinosa ${ }^{1 *}$ [D
}

\begin{abstract}
Background: Human central memory CD4 T cells are characterized by their capacity of proliferation and differentiation into effector memory CD4 T cells. Homeostasis of central memory CD4 T cells is considered a key factor sustaining the asymptomatic stage of Human Immunodeficiency Virus type 1 (HIV-1) infection, while progression to acquired immunodeficiency syndrome is imputed to central memory CD4 T cells homeostatic failure. We investigated if central memory CD4 T cells from patients with HIV-1 infection have a gene expression profile impeding proliferation and survival, despite their activated state.
\end{abstract}

Methods: Using gene expression microarrays, we analyzed mRNA expression patterns in naive, central memory, and effector memory CD4 T cells from healthy controls, and naive and central memory CD4 T cells from patients with HIV-1 infection. Differentially expressed genes, defined by $\log _{2}$ Fold Change (FC) $\geq|0.5|$ and Log (odds) $>0$, were used in pathway enrichment analyses.

Results: Central memory CD4 T cells from patients and controls showed comparable expression of differentiation-related genes, ruling out an effector-like differentiation of central memory CD4 T cells in HIV infection. However, 210 genes were differentially expressed in central memory CD4 T cells from patients compared with those from controls. Expression of 75 of these genes was validated by semi quantitative RT-PCR, and independently reproduced enrichment results from this gene expression signature. The results of functional enrichment analysis indicated movement to cell cycle phases G1 and S (increased CCNE1, MKI67, IL12RB2, ADAM9, decreased FGF9, etc.), but also arrest in G2/M (increased CHK1, RBBP8, KIF11, etc.). Unexpectedly, the results also suggested decreased apoptosis (increased CSTA, NFKBIA, decreased RNASEL, etc.). Results also suggested increased IL-1 $\beta$, IFN- $\gamma$, TNF, and RANTES (CCR5) activity upstream of the central memory CD4 T cells signature, consistent with the demonstrated milieu in HIV infection.

Conclusions: Our findings support a model where progressive loss of central memory CD4 T cells in chronic HIV-1 infection is driven by increased cell cycle entry followed by mitotic arrest, leading to a non-apoptotic death pathway without actual proliferation, possibly contributing to increased turnover.

Keywords: HIV, Immunologic Memory, Cell Cycle, Cell Death, CD4-Positive T-Lymphocytes, Transcriptome, Homeostasis

\footnotetext{
* Correspondence: espinosa@iner.gob.mx;

hector.enrique.espinosa@gmail.com

${ }^{1}$ Department of Research in Immunology, Instituto Nacional de

Enfermedades Respiratorias Ismael Cosío Villegas, Calzada de Tlalpan 4502,

Mexico City, Mexico

Full list of author information is available at the end of the article
} International License (http://creativecommons.org/licenses/by/4.0/, which permits unrestricted use, distribution, and reproduction in any medium, provided you give appropriate credit to the original author(s) and the source, provide a link to the Creative Commons license, and indicate if changes were made. The Creative Commons Public Domain Dedication waiver (http://creativecommons.org/publicdomain/zero/1.0/) applies to the data made available in this article, unless otherwise stated. 


\section{Background}

Acute HIV infection depletes mucosal CD4 T cells, mainly effector memory $\left(\mathrm{T}_{\mathrm{EM}}\right)$ cells, rapidly and profoundly [1-3]. The ensuing chronic phase is largely asymptomatic, even though mucosal tissues are not replenished with $\mathrm{T}_{\mathrm{EM}}$ cells [4]. Simian immunodeficiency virus (SIV) infection of rhesus macaques (an animal model of human HIV disease) shows that opportunistic control infection in the chronic phase is mediated by remnant mucosal $\mathrm{T}_{\mathrm{EM}}$ cells supplied by the differentiation of central memory $\left(\mathrm{T}_{\mathrm{CM}}\right)$ cells in lymph nodes $[5,6]$. Additionally, human $\mathrm{T}_{\mathrm{CM}}$ cells are also characterized by their capacity of proliferation and differentiation into $\mathrm{T}_{\mathrm{EM}}$ cells $[7,8]$. Thus, homeostasis of $\mathrm{T}_{\mathrm{CM}}$ cells is considered a key factor sustaining the asymptomatic stage of HIV infection, while progression to acquired immunodeficiency syndrome is attributed to homeostatic failure of $\mathrm{T}_{\mathrm{CM}}$ cells $[5,6,9-12]$.

It is unclear how this homeostatic equilibrium is lost during chronic infection. CD4 T cell maturation subpopulations $\left(\mathrm{T}_{\mathrm{N}}, \mathrm{T}_{\mathrm{CM}}\right.$, and $\left.\mathrm{T}_{\mathrm{EM}}\right)$ [7] are differentially affected by HIV infection [13, 14]; with $\mathrm{T}_{\mathrm{EM}}$ cells being HIV's main target [15]. $\mathrm{T}_{\mathrm{CM}}$ cells can be infected in a lower proportion by HIV, which has led to propose that direct virion-mediated cytopathicity could gradually eliminate them, leading to poor homeostatic activity [6]. Nevertheless, direct cytopathicity by HIV [16] cannot completely explain CD4 $\mathrm{T}$ cell depletion during chronic infection [17-20], which suggests the participation of indirect pathogenic mechanisms, particularly chronic activation [12, 21]. Additionally, CD4 T cells from patients with HIV could be intrinsically altered, as suggested by the limited proportion of HIV-infected patients recovering their pre-infection CD4 $\mathrm{T}$ cells counts under virus-controlling antiretroviral therapy [22]. In this regard, we have found intrinsic dysfunctions in activated $\mathrm{T}_{\mathrm{CM}}$ cells from $\mathrm{HIV}$-infected patients, as a lowered IL-2 response and CD40L induction after T cell receptor (TCR)-mediated stimulation [23, 24], which could decrease their proliferative, differentiation, and survival capacities.

In order to determine if circulating $\mathrm{T}_{\mathrm{CM}}$ cells from HIVinfected patients have a transcriptome consistent with activation, but simultaneously with altered capacities to divide and survive, we compared the ex-vivo messenger Ribonucleic acid (mRNA) whole-genome expression patterns of CD4 $\mathrm{T}$ naive $\left(\mathrm{T}_{\mathrm{N}}\right)$ and $\mathrm{T}_{\mathrm{CM}}$ cells from $\mathrm{HIV}^{+}$patients with $\mathrm{T}_{\mathrm{N}}, \mathrm{T}_{\mathrm{CM}}$, and $\mathrm{T}_{\mathrm{EM}}$ cells from healthy controls. We found a $\mathrm{T}_{\mathrm{CM}}$ cell signature in HIV-1 infection suggesting that the loss of this subpopulation may be driven by increased cell cycle entry followed by mitotic arrest possibly leading to cell death in a non-senescent or effector-like state.

\section{Methods}

\section{Participants}

This study was approved by the boards of Instituto Nacional de Enfermedades Respiratorias Ismael Cosío Villegas (reference number B29-11), and Instituto Nacional de Ciencias Médicas y Nutrición Salvador Zubirán (reference number 1403). All patients signed written informed consent according with the Helsinki Protocol. Blood samples were obtained from $9 \mathrm{HIV}^{-}$controls, and $6 \mathrm{HIV}^{+}$patients. Patients had median $480 \mathrm{CD} 4 \mathrm{~T}$ cells/ $\mu \mathrm{L}$ blood (range 330-757), and median 121563 HIVribonucleic acid (RNA) copies/mL-blood (23 883-41 2584). Among them, patients providing $T_{C M}$ cells had viral loads of 23883,81834 and 107732 HIV RNA copies/mL-blood, and CD4 T cell counts of 439, 473 and $491 \mathrm{CD} 4 \mathrm{~T}$ cells $/ \mu \mathrm{L}$ blood, respectively. Relative telomere length was determined in samples from ten additional $\mathrm{HIV}^{-}$controls, and ten additional $\mathrm{HIV}^{+}$patients with median $628 \mathrm{CD} 4 \mathrm{~T}$ cells/ $\mu \mathrm{L}$-blood (194-1 128) and median 485882 HIV-RNA copies/ mL-blood (3 870-3 500 000). Patients were antiretroviral therapy-naive, free of opportunistic infections and malignancies, and were not taking any immunomodulatory drugs.

\section{Isolation of CD4 T cell subpopulations}

Peripheral blood mononuclear cells (PBMCs) were purified from 50 to $60 \mathrm{~mL}$ of peripheral blood by sedimentation on Lymphoprep (Fresenius Kabi Norge, Oslo, Norway). CD4 $\mathrm{T}_{\mathrm{N}}\left(\mathrm{CD} 45 \mathrm{RA}^{+} \mathrm{CCR}^{+}\right), \mathrm{T}_{\mathrm{CM}}\left(\mathrm{CD} 45 \mathrm{RA}{ }^{-}\right.$ $\left.\mathrm{CCR}^{+}\right)$and $\mathrm{T}_{\mathrm{EM}}\left(\mathrm{CD} 45 \mathrm{RA}^{-} \mathrm{CCR}^{-}\right)$cells were purified from PBMCs using immunomagnetic beads (Miltenyi Biotec, Bergisch Gladbach, Germany).

Subpopulation purity was determined according to the expression of CD4, CD45RA and CCR7, using antiCD4-APC-Cy7, anti-CD45RA-APC (BD Biosciences, San José, CA, USA), and anti-CCR7-PE (Miltenyi Biotec) fluorochrome-conjugated antibodies (See Additional file 1). Cells were analyzed in a FACSCanto II flow cytometer (BD Biosciences). Cells with purity $>90 \%$ were used. Membrane CD38 was detected with an anti-CD38biotin (Miltenyi Biotec) plus streptavidin PerCp-Cy5.5 (Biolegend, San Diego, CA, USA).

\section{RNA extraction and microarray analysis}

Total RNA was obtained from three $\mathrm{T}_{\mathrm{N}}$, three $\mathrm{T}_{\mathrm{CM}}$, and three $\mathrm{T}_{\mathrm{EM}} \mathrm{CD} 4 \mathrm{~T}$ cell samples from healthy controls, and three $\mathrm{T}_{\mathrm{N}}$ and three $\mathrm{T}_{\mathrm{CM}}$ CD4 $\mathrm{T}$ cell samples from $\mathrm{HIV}^{+}$patients, using RNeasy Mini Kit (Qiagen, Venlo, Netherlands). Each RNA sample proceeded from a different subject. Scarcity of patients' $\mathrm{T}_{\mathrm{EM}}$ cells precluded obtaining sufficient RNA.

Microarray gene expression analysis used equimolar concentrations of total RNA from $\mathrm{T}$ cell subpopulations. 
Complementary deoxyribonucleic acid (cDNA) synthesis, amplification, and gene expression profiling were performed according to the manufacturer's instructions (Affymetrix WT Sense Target labeling assay manual, California, USA). Labeled DNA was added to hybridization cocktail and injected into the array (GeneChip Human Gene 1.0 ST Array, Affymetrix). Washing and staining steps were performed in the GeneChip Fluidics Station 450 (Affymetrix). Probe arrays were scanned using a GeneChip Scanner 3000 7G (Affymetrix). Data were deposited in GEO, series record GSE73968.

Background correction and normalization were performed with Robust Multiarray Average Method (RMA) [25] using Bioconductor package [26] of R [27]. A Principal component analysis (PCA) of normalized signals from all genes in each microarray was performed using $\mathrm{R}$ [27].

Modeling gene expression was performed using linear models of Limma package [28]. The B-statistic was used as significant measure to define differentially expressed genes. This statistic is computed as the posterior odds of differential expression. It is reformulated in terms of a moderated t-statistic in which posterior residual standard deviations are used in place of ordinary standard deviations. Essentially, the B-statistic compromises between individual gene variance estimates and a single variance estimate for all genes. The probabilities are transformed to a scale that goes from -Inf to Inf using $\log$ odds. The B-statistic is analogous to the adjusted $p$ value, which addresses statistical significance for multiple comparisons. Here, genes with Log 2 Fold Change $(\mathrm{FC}) \geq|0.5|$ and Log odds $>0$ were considered as differentially expressed. Limma statistics such as adjusted $p$ value and the B statistic can be seen in Additional file 2 . FDR Benjamini Hochberg multiple testing correction [29] was applied to control the number of false positives. Both B statistic and adjusted $p$-value showed consistency across differentially expressed genes. Unsupervised 2way hierarchical clustering analysis of gene expression data was performed using Euclidian distance and average linkage with gplots [30] of $R$ [27]. Venn diagrams were made with Venny 2.0.2 [31].

Functional enrichment analyses were performed with Data Base for Annotation, Visualization and Integrated Discovery (DAVID) [32, 33], Gen Set Enrichment Analysis (GSEA) [34] and Ingenuity Pathway Analysis (IPA, QIAGEN Redwood City, CA, USA). DAVID uses a Fisher Exact test in order to determine gene-enrichment in annotation terms. A gene set is enriched when the proportion of genes in a list that falls into an annotation term differs from the background model. The EASE score is a modified Fisher exact $p$-value. Basically, if $n$ is the number of genes in the list that falls into a given annotation term, $n-1$ is used to compute the $p$-value [32,
33]. Gene set enrichment methods also implement strategies for addressing the issue of multiple testing hypotheses. GSEA uses a ranking procedure to produce a gene list from the full expression matrix. This is done by computing an Enrichment Score (ES(S)). It controls the ratio of false positives to the total number of gene sets attaining a fixed level of significance using FDR [34]. IPA assesses enrichment (i. e. biological functions that could be increased or decreased given the observed gene expression patterns) using a Fisher exact $p$-value. Additionally, it computes a $\mathrm{Z}$ score that allows inferring upstream transcriptional regulators and expectable enriched functions, based on statistical significance by comparing the match between observed and predicted up/down regulation patterns. The null model is referred as activation Z-score [35]. Predicted regulation patterns are based on previously reported causal relationships between relevant genes and functions [35].

\section{Semi-quantitative real-time PCR}

We used B2M, GAPDH, POLR2A, and TBP as reference genes to normalize expression. RNA proceeded from the samples used for microarray analysis. cDNA was synthesized from $\sim 100$ ng total RNA with Transcriptor First Strand cDNA Synthesis Kit (Roche Applied Science, Mannheim, Germany), using random hexamers and performing one cycle of $10 \mathrm{~min} 25^{\circ} \mathrm{C} ; 30 \mathrm{~min} 55^{\circ} \mathrm{C}$, and 5 min $85^{\circ} \mathrm{C}$. cDNA was stored at $-20^{\circ} \mathrm{C}$ until use. PCR amplifications were performed by high-throughput gene expression analysis using DNA binding dye Evagreen (SsoFast MasterMix, Biorad, California, USA) for product detection, and specific primers for each gene (DELTAgene Assays, Fluidigm Corporation, California, USA). Specific target pre-amplification of each cDNA and a cleanup step were performed as described elsewhere [36].

We performed semiquantitative RT-PCR using Fast Gene Expression Analysis with EvaGreen (Biorad), following the Biomark System Protocol (Fluidigm Corporation, California, USA). Assay mixes $(100 \mu \mathrm{M}$ of each pair of primers, 2X Assay Loading Reagent, and 1X TE buffer), sample mixes (pre-amplified cDNA, 2X SsoFast MasterMix (BioRad), and 20X DNA Binding Dye Sample Loading Reagent (Fluidigm), were loaded into a 96.96 Dynamic Array (Fluidigm), using the IFC Controller HX (Fluidigm), and were then transferred to a BioMark HD device (Fluidigm) for the PCR cycles $\left(40 \mathrm{~min} 70^{\circ} \mathrm{C}\right.$, 30s $60{ }^{\circ} \mathrm{C}$; 60 s $95{ }^{\circ} \mathrm{C}$, then 30 cycles of $5 \mathrm{~s} 96{ }^{\circ} \mathrm{C}, 60 \mathrm{~s} 60^{\circ} \mathrm{C}$ ). Melting curves were determined at the 60 to $95{ }^{\circ} \mathrm{C}$ rise, with a temperature change rate of $1{ }^{\circ} \mathrm{C} / 3 \mathrm{~s}$. Ct values were obtained with Fluidigm Real-Time PCR Analysis Version 4.1.3 software (Fluidigm).

Only Ct values $<30$ and amplicons with only 1 melting curve were used. Geometric means of four reference 
genes were used to normalize expression data [37]. Relative expression was calculated as $\Delta \Delta \mathrm{Ct}$. Expression of each gene was determined with six technical replicates per sample. Normality was verified using KolmogorovSmirnov test, which quantifies the distance between the empirical distribution of the sample and the cumulative distribution of the reference distribution, which in this case is assumed to be normal. Group differences were analyzed with Student's $t$ test. Data management and statistics were done with Reshape [38] and fBasics [39] packages of $\mathrm{R}$ [27].

\section{Relative telomere length}

Telomere PNA kit/FITC (Dako, São Paulo, Brazil) was used following the manufacturer's instructions, including thymocytes from 6-week old mice as reference for normalization. Briefly, samples were prepared by mixing $10^{6}$ mouse thymocytes and $10^{6} \mathrm{~T}_{\mathrm{CM}}$ cells. The mixture was distributed into four tubes. $150 \mu \mathrm{l}$ of FITC-labeled peptide nucleic acid (PNA) probe solution was added into two tubes while $150 \mu \mathrm{l}$ of unlabeled PNA probe solution was added into the other two. Samples were hybridized in a pre-warmed heating block (TB2 Thermoblock, Biometra, Göttingen, Germany) set at $82^{\circ}$ C, $10 \mathrm{~min}$, and left overnight at room temperature. Samples were washed twice. Between washing steps, samples were heated to $40{ }^{\circ} \mathrm{C}$ in a pre-warmed TB2 Thermoblock (Biometra) for $10 \mathrm{~min}$. Samples were resuspended in $250 \mu \mathrm{L}$ of DNA staining solution (1X), and stored overnight at $4{ }^{\circ} \mathrm{C}$, away of light. Then, samples were analyzed by flow cytometry in a FACSCanto II (BD Biosciences).

\section{Results}

$\mathrm{T}_{\mathrm{CM}}$ cells from $\mathrm{HIV}^{+}$patients are not more differentiated and are not more senescent

Unsupervised principal component analysis of normalized whole genome expression data segregated samples of each maturation subpopulation, and further separated samples originating from persons with HIV and samples from controls (Fig. 1a). Thus, phenotypebased classification of differentiation subpopulations $[7,8]$ reliably reflected distinct gene expression programs, as previously reported [40-42], which were altered by HIV infection.

We asked if differential gene expression by patients' and controls' $\mathrm{T}_{\mathrm{CM}}$ cells reflected greater differentiation of patients' cells (towards effector stages) [23, 24]. Using the criteria defined in methods $\left(\log _{2} \mathrm{FC} \geq|0.5|\right.$ and $\log$ (odds) $>0$ ) we looked in the whole transcriptome for all differentially expressed genes in the following pair-wise comparisons of CD4 $\mathrm{T}$ cell subpopulations from controls: $\mathrm{T}_{\mathrm{CM}}$ vs. $\mathrm{T}_{\mathrm{N}}, \mathrm{T}_{\mathrm{EM}}$ vs. $\mathrm{T}_{\mathrm{CM}}$, and $\mathrm{T}_{\mathrm{EM}}$ vs. $\mathrm{T}_{\mathrm{N}}$ (arrows $\mathrm{a}, \mathrm{b}$ and $\mathrm{c}$ in Fig. 2a). The resulting 1858 differentially expressed genes are subsequently referred to as differentiation-related genes (corresponding to subpopulations in distinct stages of differentiation). We performed an unsupervised 2-way hierarchical clustering analysis of these 1858 differentiation-related genes (Fig. 1b, and Additional file 3). $\mathrm{T}_{\mathrm{N}}$ and $\mathrm{T}_{\mathrm{CM}}$ cells from patients grouped with their counterparts from controls (Fig. 1b). Samples of a same subpopulation were assigned to a same node (green circles 1, 2, and 3 on Fig. 1b), regardless of their HIV status. The expression of the differentiation-related genes progressively decreased or increased in the order of linear differentiation $\left(\mathrm{T}_{\mathrm{N}} \rightarrow \mathrm{T}_{\mathrm{CM}} \rightarrow \mathrm{T}_{\mathrm{EM}}\right)$, agreeing with previous reports [40-43] (Fig. 1c). For instance, LEF1, ACTN1, FOXP1, IL6ST and CERS6 reportedly undergoing downregulation in naive $\mathrm{T}$ cells after antigen recognition and differentiation [44-48], along with TAF4B, appeared progressively down regulated when samples were ordered according to the linear model of peripheral differentiation (Fig. 1c, left panel). These changes agree with previous reports [42]. Conversely, differentiation and effector function-associated transcripts, like EOMES, TBX21 (t-bet), PRDM1 (Blimp-1) [49, 50], GZMA and PRF1 [51, 52], were gradually increased in the same order (Fig. 1c right panel). A same pattern was followed by the expression of KLRG1, an indicator of replicative senescence [53, 54] (Fig. 1c). TBX21 (t-bet) was the only gene with increased expression in $\mathrm{T}_{\mathrm{CM}}$ cells from $\mathrm{pa}$ tients, compared with controls $(p=0.003)$, which, along with the increased expression of IL12R e IL18R, suggests a Th1-skewed response driven by HIV infection. A Th1skewed response was also predicted by Ingenuity Canonical Pathway analysis (See Additional file 4). Thus, $\mathrm{T}_{\mathrm{CM}}$ cells from patients did not seem to be more differentiated than their counterparts from controls, but appeared polarized to Th1 functions.

We then asked if patients' $\mathrm{T}_{\mathrm{CM}}$ cells had a longer replicative history, which would entail a shortening of telomeres. We did not find any difference in relative telomere length between $\mathrm{T}_{\mathrm{CM}}$ cells from patients and controls $(p=0.737$, Fig. 1d), agreeing with KLRG1 expression $[53,54]$, and suggesting that they are not in a more senescent state.

\section{$\mathrm{T}_{\mathrm{CM}}$ gene expression signature in HIV infection}

Having ruled out a greater differentiation of patients' $\mathrm{T}_{\mathrm{CM}}$ cells, we investigated if the gene expression signature of these cells revealed a functional state that could explain loss of homeostatic capacity. Using the criteria defined in methods $\left(\log _{2} \mathrm{FC} \geq|0.5|\right.$ and $\log$ (odds) $>0$ ), we looked for genes that were differentially expressed by $\mathrm{T}_{\mathrm{CM}}$ cells from $\mathrm{HIV}^{+}$patient and $\mathrm{T}_{\mathrm{CM}}$ from controls. We found a total of 210 differentially expressed genes. We refer to this 210- gene list as the gene expression signature of $\mathrm{T}_{\mathrm{CM}}$ cells in HIV infection (See Fig. 2a 


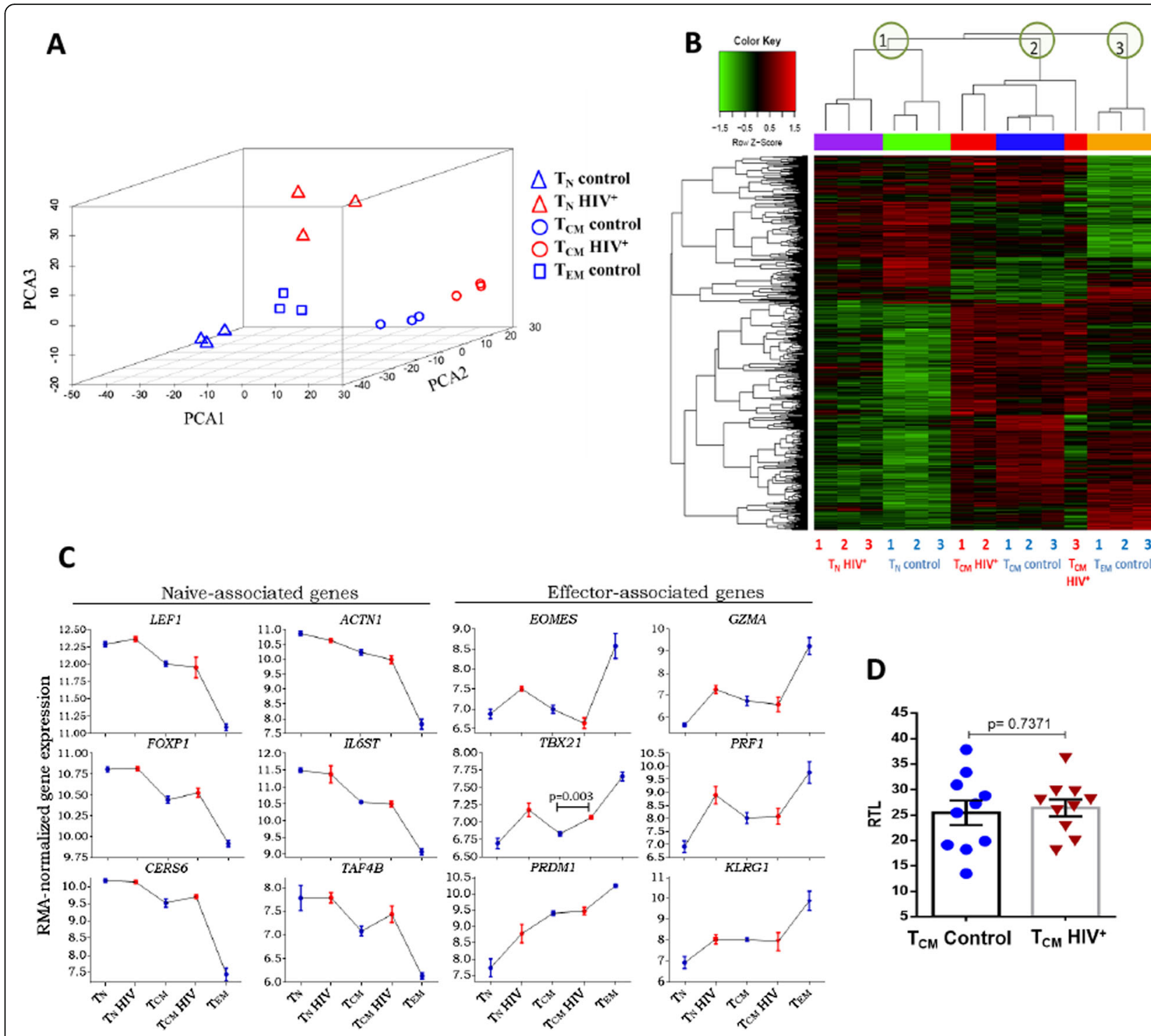

Fig. 1 Gene expression does not support greater differentiation or senescence of $\mathrm{T}_{\mathrm{CM}}$ cells from $\mathrm{HIV}^{+}$patients. a Principal component analysis of the entire microarray data set of each subpopulations from $\mathrm{HIV}^{+}$patients (red triangles and red circles) and controls (blue triangles, blue circles and blue squares). The first three principal components are shown, accounting for $55 \%$ of variance in a three dimensional plot. b Heat map resulting from hierarchical clustering of genes related with normal differentiation (pairwise comparisons between not infected subpopulations). Each row represents a differentially expressed gene. Each column represents each independent sample. The unsupervised two-way hierarchical clustering is shown as a dendrogram for genes (left), and a dendrogram for samples (top). In the upper dendrogram (samples) the independent resulting nodes, each one corresponding to a maturation subpopulation, is encircled in green. c Sequential downregulation of selected naïve-associated genes, and sequential upregulation of selected effector-associated genes when samples are arranged according to the linear differentiation model. Data are represented as means \pm 1 SEM of three donors (blue) and three patients (red). TBX21 expression difference between $T_{C M}$ and $T_{C M}$ HIV was analyzed with Student's t test. d Relative telomere length of central memory CD4 T cells $\left(T_{C M}\right)$ from HIV patients (red triangles) and controls (blue circles), Student's t-test was used to compare groups. We were unable to obtain sufficient RNA from TEM cells from patients due to their small number

arrow d, b red oval and Additional file 2). This gene expression signature was obtained from the transcriptome independently of the list of 1858 differentiationrelated genes. Among these 210 differentially expressed genes, 137 were absent in all other pairwise comparison (Fig. 2a, b). Hierarchical clustering analysis showed clear and consistent differences in the relative expression of these 210 genes between patients and controls (Fig. 2c). Of note, biological replicates were very homogeneous.

We analyzed the HIV $\mathrm{T}_{\mathrm{CM}}$ signature with the enrichment analysis tools IPA, GSEA, and DAVID. These different analyses consistently yielded four general functional categories that were modified in $\mathrm{T}_{\mathrm{CM}}$ cells 


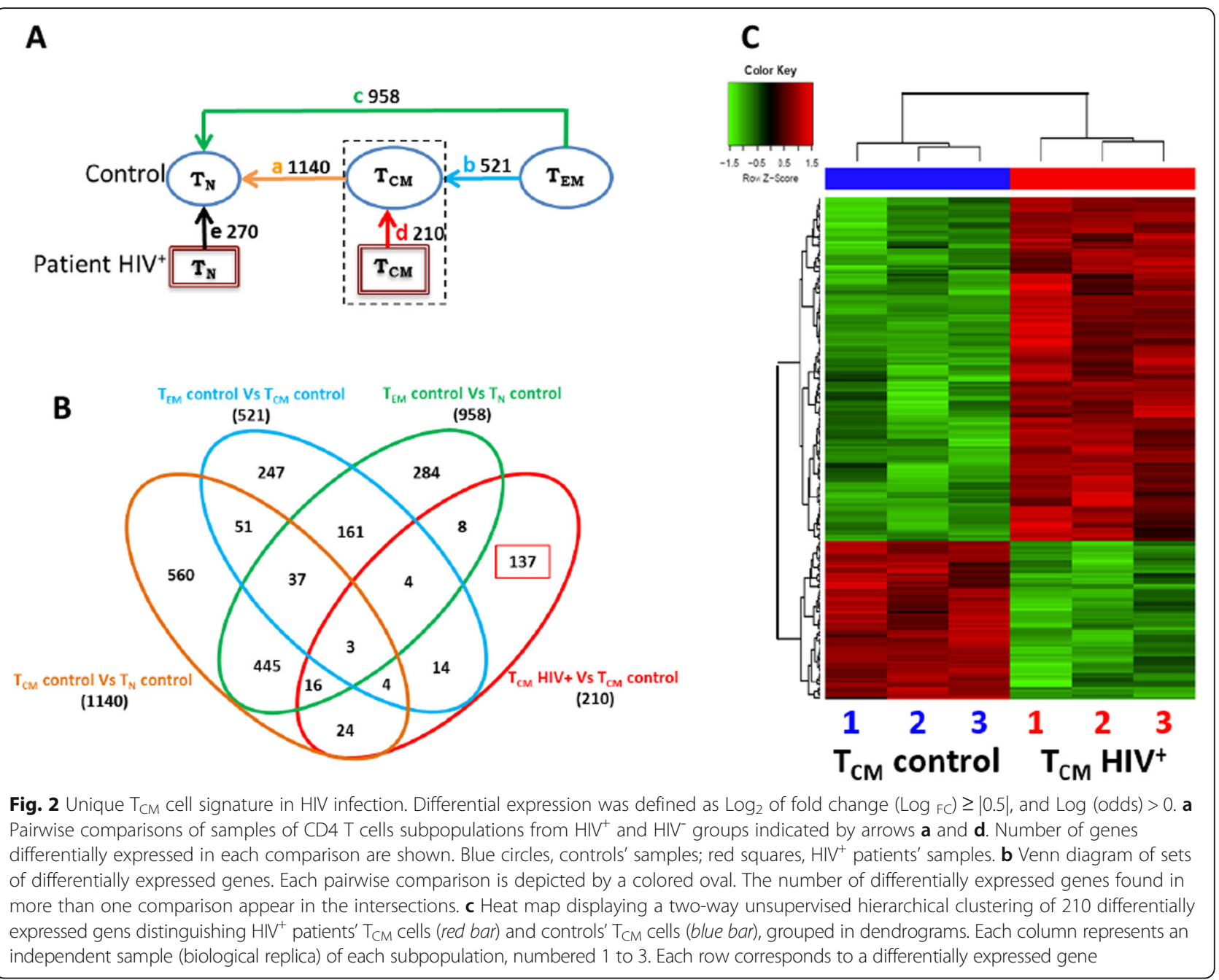

from patients: cell cycle, DNA damage and repair, apoptosis, and immune responses (Table 1). Notably, the 137 genes uniquely distinguishing $\mathrm{T}_{\mathrm{CM}}$ cells from patients and controls (Fig. 2b red oval) sufficed to yield the same four functional categories when analyzed with DAVID and IPA. This suggests that the enriched functions largely depend on the $\mathrm{T}_{\mathrm{CM}}$ cell signature. GSEA rendered a larger set of altered immune functions, likely because it uses data from the entire microarray, and because it detects more modest changes when the members of a function or pathway show a strong correlation [34] (Table 1). GSEA identified Toll-like receptors (TLR), type I interferons, IL1, and NLRs signaling, plus $N F \kappa B$ activation, all of them related to an inflammatory milieu. Independently, Ingenuity Upstream Regulator Analysis [35] assigned the greatest z-scores and the most significant $p$-values to the activity of IL-1B, TNF, NFKB complex, and CCL5, as possible upstream molecules eliciting the expression changes constituting the $\mathrm{T}_{\mathrm{CM}}$ signature (See Additional file 5, upstream analysis). Cell cycle, DNA damage and repair, and apoptosis (greatly related functions $[55,56])$ appeared consistently in the output of all enrichment analysis tools (Table 1). There were several functional categories closely related with G0/G1/S transition and G2/M checkpoints in the output of GSEA analysis. IPA, which weighs its predictions, displayed increased proliferation and cell survival, decreased apoptosis and decreased cell death. In contrast, IPA's output simultaneously indicated an increase in cytostasis, movement to interphase, and a decrease in mitosis (Table 1).

We re-analyzed mRNA expression by RT-PCR of 91 genes of the HIV $\mathrm{T}_{\mathrm{CM}}$ signature that were associated with enriched functions, and $B 2 M, G A P D H, P O L R 2 A$, and TBP as reference genes. This analysis validated 75 genes (82\%) of the signature (See Additional file 6). Five genes failed amplification, and 11 were not differentially expressed when assessed by RT-PCR. The expression of reference genes did not differ between samples (See Additional file 7). An analysis with IPA using only the 75 validated genes yielded the same enriched functions and pathways as microarray data (Fig. 3a, b, c, 
Table 1 Enriched categories of functions according to TCM gene expression signature in HIV infection

\begin{tabular}{|c|c|c|c|c|c|c|}
\hline \multirow[t]{2}{*}{ General category } & \multicolumn{2}{|l|}{ DAVID } & \multirow{2}{*}{$\begin{array}{l}\text { GSEA } \\
\text { FDR }<0.05, p<0.001\end{array}$} & \multicolumn{3}{|l|}{ IPA } \\
\hline & EASE $<0.05$ & $\begin{array}{l}\text { Number of } \\
\text { genes }\end{array}$ & & $p<0.01$ & $\begin{array}{l}\text { Number of } \\
\text { genes }\end{array}$ & $\begin{array}{l}\text { Prediction } \\
\text { sense }\end{array}$ \\
\hline \multirow[t]{9}{*}{ Cell cycle } & Cell cycle & 15 & DNA replication & $\begin{array}{l}\text { Proliferation of tumor cell } \\
\text { lines }\end{array}$ & 31 & Positive \\
\hline & Cell division & 10 & Cell cycle & Proliferation of cells & 53 & Positive \\
\hline & mitosis & 9 & Mitotic M/G1 & Cytostasis & 6 & Positive \\
\hline & & & G1/S transition & $\begin{array}{l}\text { Cytostasis od tumor cell } \\
\text { lines }\end{array}$ & 5 & Positive \\
\hline & & & Cell cycle check points & $\begin{array}{l}\text { Interphase of tumor cell } \\
\text { lines }\end{array}$ & 11 & Positive \\
\hline & & & $\begin{array}{l}\text { Cyclin E associated event during } \\
\mathrm{G} 1 / \mathrm{S} \text { transition }\end{array}$ & Cell survival & 28 & Positive \\
\hline & & & Assembly of pre-replicative complex & Interphase & 13 & Positive \\
\hline & & & G0 and early G1 & Mitosis & 10 & Negative \\
\hline & & & G2/M check points & & & \\
\hline \multirow[t]{3}{*}{$\begin{array}{l}\text { DNA damage or } \\
\text { repair }\end{array}$} & $\begin{array}{l}\text { p53 signaling } \\
\text { pathway }\end{array}$ & 5 & $\begin{array}{l}\text { p53 dependent G1 DNA damage } \\
\text { response }\end{array}$ & & & \\
\hline & $\begin{array}{l}\text { ATM signal } \\
\text { pathway }\end{array}$ & 3 & & & & \\
\hline & $\begin{array}{l}\text { Cell cycle } \\
\text { checkpoints }\end{array}$ & 5 & & & & \\
\hline \multirow[t]{3}{*}{ Apoptosis } & Apoptosis & 13 & & $\begin{array}{l}\text { Apoptosis of tumor cell } \\
\text { lines }\end{array}$ & 32 & Negative \\
\hline & & & & Cell death of cancer cells & 6 & Negative \\
\hline & & & & $\begin{array}{l}\text { Apoptosis of cervical cancer } \\
\text { cell lines }\end{array}$ & 10 & Negative \\
\hline \multirow[t]{10}{*}{$\begin{array}{l}\text { Immune } \\
\text { responses }\end{array}$} & & & Toll endogenous pathway & $\begin{array}{l}\text { Synthesis of reactive oxygen } \\
\text { species }\end{array}$ & 7 & Positive \\
\hline & & & IL1 signaling & & & \\
\hline & & & IFN-alpha/beta signaling & & & \\
\hline & & & $\begin{array}{l}\text { Chemokine receptors bind } \\
\text { chemokines }\end{array}$ & & & \\
\hline & & & NOD like receptors signaling & & & \\
\hline & & & NFKB activation by IKKS complex & & & \\
\hline & & & Myd88 cascade & & & \\
\hline & & & TLR4 signaling & & & \\
\hline & & & IL12 pathway & & & \\
\hline & & & FOXO Pathway & & & \\
\hline
\end{tabular}

Enriched categories of functions according to differential expression of 210 genes in $\mathrm{T}_{\mathrm{CM}}$ cells from HIV ${ }^{+}$patients and controls. DAVID and IPA tools show in a column the number of genes supporting each prediction. EASE Score is the $P$-Value of a modified Fisher Exact test of the significance of gene enrichment in a gen-set. FDR: False discovery rate. In IPA, the sign indicates if the function would be up-regulated (positive) or down-regulated (negative)

$\mathrm{d}$, e, and Additional file 8). While some genes were related with more than one function, many were related exclusively with one function (Fig. 3f), supporting an unambiguous prediction. Finally, analyzing the $\mathrm{T}_{\mathrm{CM}}$ cells used for microarray and RT-PCR analyses, we found that surface expression of the CD38 protein was more frequent among $\mathrm{T}_{\mathrm{CM}}$ cells from patients than among those from controls, consistent with mRNA results (Fig. 3g).

\section{A model of $\mathrm{T}_{\mathrm{CM}}$ cell death in HIV infection}

Since the predictions of increased proliferation and increased cytostasis were incompatible, and the prediction of reduced apoptosis did not agree with previous evidence [13, 57-60], we took into account that enrichment tools base their predictions on a broad set of previous findings, ranging from very particular to very general ones. Accordingly, we investigated if the predictions were based on more demarcated processes, and if these 


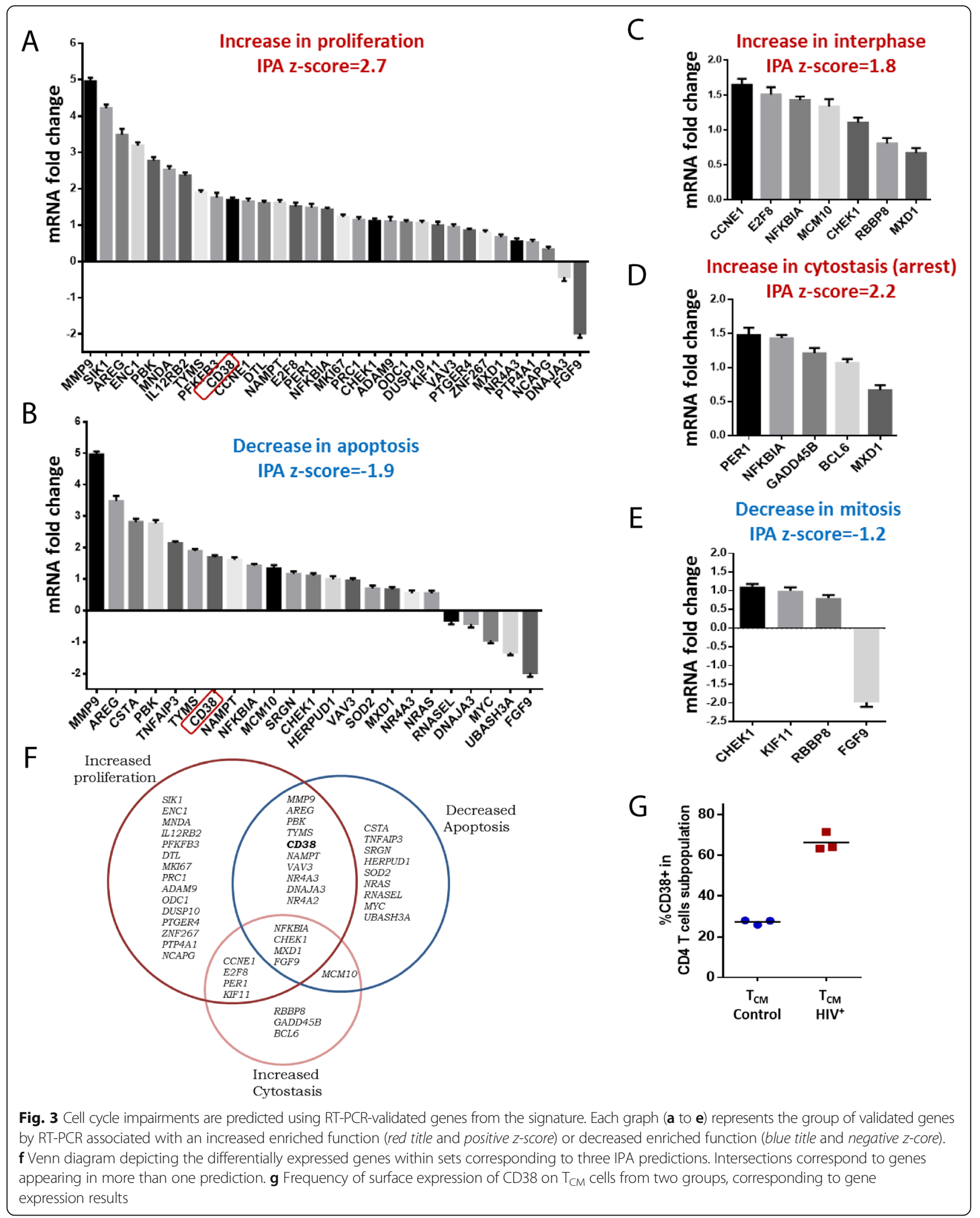


processes were compatible. With this purpose, we reviewed the references supporting IPA predictions, allocating the indicated genes to the cell cycle phase that they regulated. We found that genes in all the predictions could be assigned to particular phases in the cell cycle, and implied no conflicts (Fig. 4), with the exception of some proliferation-predicting genes, which did not relate with cell cycle in the supporting evidence.

The HIV $\mathrm{T}_{\mathrm{CM}}$ signature is compatible with an enhanced progression from $\mathrm{G0}$ to $\mathrm{S}$ phase (CCNE1 [61, 62], MKI67 [63, 64], IL12RB2 [65, 66], ADAM9 [67], E2F8 [68], MXD1 [69], MCM10 [70], BCL6 [71-73]), but not with progression to later stages. Simultaneously, the expression patterns of other genes suggest arrest in G2/M (CHK1 [74], GADD45B [75], PER1 [76], NFKBIA [77], RBBP8 [78], KIF11 [79]). For instance, accumulation of $C C N E 1$ is necessary for $\mathrm{G} 1 \rightarrow \mathrm{S}$ transition, but its overexpression is associated with chromosome destabilization and DNA damage $[61,62]$. In turn, CHK1 expression is required for cycle arrest in G2 following DNA damage [74]. These observations suggest that the cell processes expectable from the HIV $\mathrm{T}_{\mathrm{CM}}$ signature can be integrated within the cell cycle, and they indicate increased cycling up to $\mathrm{S}$ phase, followed by arrest in G2/M. Remarkably, since cycle arrest leads to cell death $[55,56]$, it was unexpected to find that the expression patterns of CSTA [80], RNASEL [81] NR4A2 [82] and NFKBIA [77] predicted an inhibition of caspase-3 mediated apoptosis (Fig. 4).

\section{Discussion}

We identified and validated a gene expression signature of $\mathrm{T}_{\mathrm{CM}}$ cells in the context of chronic HIV infection that led us to a model of $\mathrm{T}_{\mathrm{CM}}$ cell death in HIV infection, also supported by additional observations and previous reports.

It could be argued that a model based on mRNA presence, but not demonstrating the presence of encoded proteins [83], is unfounded. In this regard, recent studies and reassessments found that mRNA changes explained 87 to $92 \%$ of corresponding protein changes [84, 85], as found in mouse dendritic cells responding to lipopolysaccharide [86]. Further, $81 \%$ of protein levels were explained by mRNA levels using a large scale proteome and mRNA analysis in NIH3T3 cells [87]. Therefore, we consider that we have evidence to propose a model of $\mathrm{T}_{\mathrm{CM}}$ cell death in HIV infection.

Our interest in intrinsic $\mathrm{T}_{\mathrm{CM}}$ cell alterations in patients with HIV originated from studies showing their importance in CD4 T cell homeostasis under HIV infection [10, 12, 57, 88-90]. Our previous studies on activated $\left(\mathrm{CD} 38^{+}\right) \mathrm{T}_{\mathrm{CM}}$ cells, particularly those from HIVinfected patients, showed IFN- $\gamma$-skewed cytokine responses that were un-connected to CD40L induction, along with a lowered IL-2 production [23, 24]. Given this functionality, $\mathrm{T}_{\mathrm{CM}}$ cells seemed differentiated towards an effector fate [40, 42, 43, 91, 92]. However, in the present study we found that $\mathrm{T}_{\mathrm{CM}}$ cells' gene expression profile was incompatible with the $\mathrm{T}_{\mathrm{EM}}$ maturation category. Additionally, we found no decrease in relative telomere length (RTL) of patients' $\mathrm{T}_{\mathrm{CM}}$ cells, which is expectable of cells with a longer replicative history $[7,8]$, such as $\mathrm{T}_{\mathrm{EM}^{-}}$cells. Moreover, KLRG1 expression, which is proportional to replicative history [53], was similar in $\mathrm{T}_{\mathrm{CM}}$ cells from patients and controls, but greatly increased in more differentiated $\mathrm{T}_{\mathrm{EM}}$ cells. These findings support that HIV infection was not associated with an

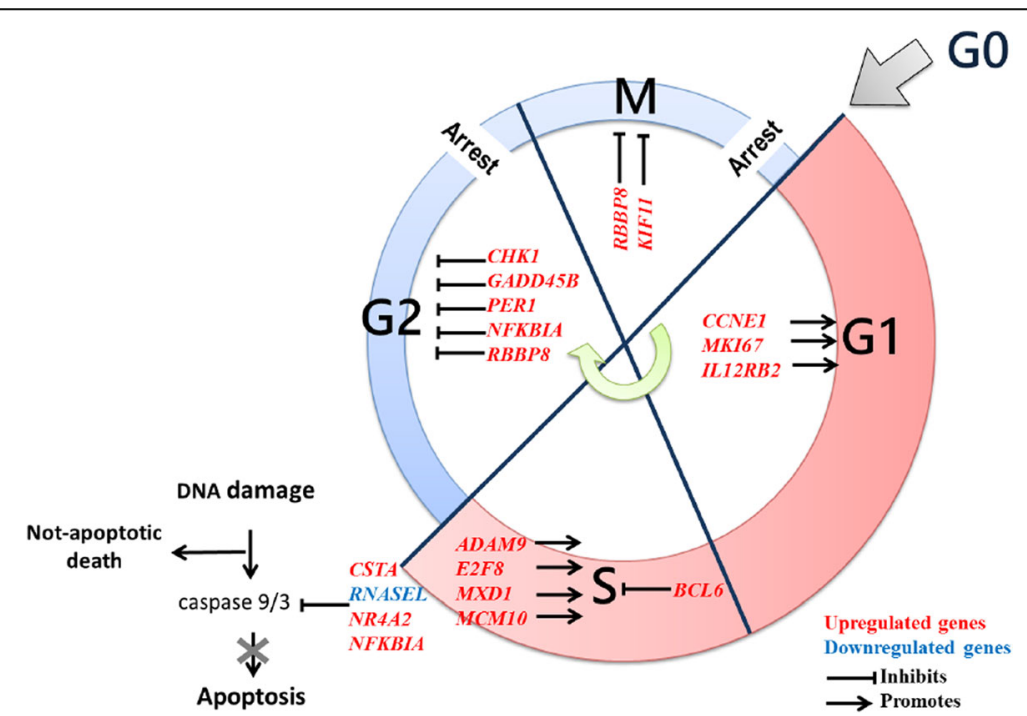

Fig. 4 Allocation of HIV-related $T_{C M}$ signature genes in the cell cycle phases they regulate. These genes suggest a promoted progress from G0 to $\mathrm{S}$, followed by arrest in G2/M cell cycle phases, and decreased apoptosis 
enhanced $\mathrm{T}_{\mathrm{CM}}$ cell differentiation. Nevertheless, $\mathrm{T}_{\mathrm{CM}}$ patients' cells showed an increased expression of the Th1associated transcription factor T-bet $[49,93]$, suggesting that our previous findings were attributable to Th1 polarization rather than differentiation.

The homogeneity and consistency of the $\mathrm{T}_{\mathrm{CM}}$ signature in HIV infection (Fig. 2c) contrasts with the great differences between patients' viral loads (23883, 81834 and 107732 HIV RNA copies/mL-blood). This may seem more important considering that even transient changes in viral load can greatly influence gene expression in total CD4 T cells [94]. However, patients' CD4 T cell counts, the strongest predictor of subsequent disease progression [95] are close (439, 473 and 491 CD4 T cells $/ \mathrm{mm}^{3}$ blood, respectively), and lie above the threshold for the occurrence of most opportunistic infections (200 cells/mm3 blood [95]). This could suggest that the $\mathrm{T}_{\mathrm{CM}}$ gene expression signature is not dependent of the magnitude of viral replication during the chronic phase of infection, but it could rather be related with irreversible events from the initial phase of infection and/or with the magnitude of circulating CD4 T cell loss in the chronic phase.

A thorough pathway enrichment analysis of the HIV $\mathrm{T}_{\mathrm{CM}}$ signature suggested enhanced cell cycle entry and proliferation. Under closer inspection, however, we observed that proliferation-predicting genes corresponded to functions upstream of $\mathrm{S}$ phase. Conversely, this analysis also predicted cell cycle arrest due to functions occurring in G2 or M. If cell cycle promotion and arrest occur in a same $\mathrm{T}_{\mathrm{CM}}$ cell, cycling would not imply cell division [58], since G2/M arrest would lead to death [96]. Additionally, overexpression of DNA damage and repair-related genes by patients' $\mathrm{T}_{\mathrm{CM}}$ cells are consistent with a failed division after $\mathrm{S}$ phase.

Our model could integrate partial observations from previous studies on cell cycle in HIV infection, providing a wider view of the fate of $\mathrm{T}_{\mathrm{CM}}$ cells. In a previous study, CD4 $\mathrm{T}$ cells from patients with HIV that were ex vivo in $\mathrm{S}$ phase (mostly $\mathrm{T}_{\mathrm{CM}}$ ) would die after in vitro stimulation more frequently than CD8 $\mathrm{T}$ cells [58]. However, patients' cells were not compared with $\mathrm{CD} 4 \mathrm{~T}$ cells from $\mathrm{HIV}^{-}$controls. Contrastingly, our comparison with cells from controls, and our characterization of CD4 $\mathrm{T}$ cell subpopulations, suggested that cycle-related death was due to HIV infection, and involved predominantly $\mathrm{T}_{\mathrm{CM}}$ cells.

Another group reported arrest in G1 based on the accumulation of cycling cells in G1 among total circulating CD4 $\mathrm{T}$ cells [97]. However, since $\mathrm{T}_{\mathrm{CM}}$ cells comprise only about $25 \%$ of circulating CD4 T cells [42], they were possibly not well represented in that study. Nevertheless, an increased proportion of $\mathrm{Ki} 67^{+}$cells in the G1 phase provided evidence that $\mathrm{CD} 4 \mathrm{~T}$ cells more frequently entered cell cycle in HIV infection, as previously demonstrated $[98,99]$. Since dead cells are readily removed from blood [100], it is possible that the reported ex vivo increase of CD4 T cells in G1 was the result of rapid removal from blood of cells that died in a further phase. Our findings were consistent with a promoted entry into cell cycle (Fig. 4), and notably, they suggested that arrest occurred in the later phases G2 and/or M.

Our results could imply that incorporation of nucleotide analogues by $\mathrm{T}_{\mathrm{CM}}$ cells from patients with HIV could reflect entrance to a fatal cycle, rather than proliferation $[101,102]$. Evidence of division and viability will be required to dismiss this possibility. In our model, $\mathrm{T}_{\mathrm{CM}}$ cell turnover reflects to some extent, death, and not actual proliferation. Accordingly, we found no difference in telomere length between $\mathrm{T}_{\mathrm{CM}}$ cells from controls and patients.

An analogous implication pertains to apoptosis. Previous studies have reported increased apoptosis in total $[58,103,104]$ and in $\mathrm{T}_{\mathrm{CM}}[58,105] \mathrm{CD} 4 \mathrm{~T}$ cells from patients with HIV, which is an explanation of CD4 T cell loss in chronic infection [106]. These and other studies [13, 57-60] inferred apoptosis by demonstrating Annexin $\mathrm{V}$ binding to viable cells; however, it has been demonstrated that Annexin V binding can be increased in other cell death pathways [107-110]. In this regard, we found that HIV infection altered the expression of a considerable number of genes that indicated that apoptosis would not be favored. A possible explanation of this discordance with previous studies could be that different cell death pathways may coexist with caspase 3mediated $\mathrm{T}_{\mathrm{CM}}$ cell death in HIV infection, as suggested by other studies $[107,111]$. Also, $\mathrm{T}_{\mathrm{CM}}$ subpopulation is heterogeneous $[10,112]$, and cells under apoptosis might not be reflected in microarray data. Therefore, we propose that an additional programmed cell death pathway may be in involved in $\mathrm{T}_{\mathrm{CM}}$ cell death after cell cycle arrest. A likely pathway is pyroptosis, an inflammatory programmed cell death pathway driven by pro-inflammatory signals, such as bacterial lipopolysaccharide and IL-1 $\beta$ [113]. This pathway has been suggested by previous reports $[111,114]$, and agrees with the presence in blood of triggers of pyroptosis as bacterial lipopolysaccharide (LPS) [115] and IL-1 $\beta$ [116] in HIV infection. Additionally, increased concentrations of IL-18, a cytokine liberated during pyroptosis, has been found in the blood of patients with HIV [117].

\section{Conclusions}

In summary, we propose a model of $\mathrm{CD} 4 \mathrm{~T}_{\mathrm{CM}}$ cell death in chronic HIV infection based on a gene expression signature unique to this subpopulation. According to it, 
CD4 $\mathrm{T}_{\mathrm{CM}}$ cell loss in HIV infection may be driven in vivo by increased cell cycle entry followed by G2/M arrest, possibly leading to a non-apoptotic cell death, arguably pyroptosis. Further experimental work is required to validate the processes involved in this model.

\section{Additional files}

Additional file 1: CD4 T cell subpopulations were separated with at least $90 \%$ purity. Dot plots showing the sequential gating strategy used to analyze the frequency of CD4 T cell subpopulations. (PDF $173 \mathrm{~kb}$ )

Additional file 2: $C D 4 T_{C M}$ cell signature in HIV infection. Table that lists the genes that were differentially expressed by $T_{C M}$ cells from patients with HIV, constituting the HIV T $\mathrm{CM}$ signature. (XLS $56 \mathrm{~kb}$ )

Additional file 3: RMA-normalized gene expression of differentiation-related genes. Table that lists differentiation-related genes and their normalized expression values in each CD4 T cell subpopulation sample. (XLS $631 \mathrm{~kb}$ )

Additional file 4: Th1 polarization pathway enriched in the $T_{C M}$ from HIV infection. Diagram displaying Th1 polarization pathway enriched in the $T_{C M}$ cell signature in HIV infection. (PDF $366 \mathrm{~kb}$ )

Additional file 5: Upstream analysis of gene expression signature in $T_{C M}$ from HIV infection. Diagram displaying the upstream analysis of molecules related with gene expression signature in $T_{C M}$ from HIV infection. (PDF $807 \mathrm{~kb}$ )

Additional file 6: RT-PCR validation of $T_{C M}$ cell signature in HIV infection. Table that lists the results of RT-PCR validation of 91 genes of $T_{C M}$ cell signature in HIV infection. (XLS $40 \mathrm{~kb}$ )

Additional file 7: Expression of four reference genes used in validation by RT-PCR. Figure that shows the expression of four reference genes used in validation by RT-PCR. (PDF $130 \mathrm{~kb}$ )

Additional file 8: Ingenuity functional prediction analysis of the signature of $T_{C M}$ cells in HIV infection. Tables that show the five functions reported by ingenuity functional prediction analysis (IPA) of RT-PCR validated genes of the $T_{C M}$ cell signature in HIV infection. (PDF $166 \mathrm{~kb}$ )

\section{Abbreviations}

cDNA: Complementary DNA; DAVID: Data Base for Annotation, Visualization and Integrated Discovery; DNA: Deoxyribonucleic acid; FC: Fold change; FDR: Falser discovery rate; GSEA: Gen Set Enrichment Analysis; HIV: Human Immunodeficiency Virus; IFN: Interferon; IL: Interleukin; IPA: Ingenuity Pathway Analysis; LPS: Lipopolysaccharide; mRNA: Messenger Ribonucleic Acid; NLRs: NOD - like receptors; PBMCs: Peripheral blood mononuclear cells; PCA: Principal component analysis; PCR: Polymerase chain reaction; PNA: Peptide nucleic acid; RANTES: Regulated on activation, normal T cell expressed and secreted. Also CCR5; RMA: Robust Multiarray Average Method RNA: Ribonucleic acid; RT-PCR: Real time polymerase chain reaction; SIV: Simian immunodeficiency virus; T СM: Central memory CD4 T cells; TCR: T cell receptor; TEM: Effector memory CD4 T cells; TLR: Toll - like receptor; $T_{N}$ : Naive CD4 T cells; TNF: Tumor necrosis factor

\section{Acknowledgments}

Gustavo Olvera-García is a doctoral student at Programa de Doctorado en Ciencias Biomédicas, Universidad Nacional Autónoma de México (UNAM) and received fellowship number 220275 from CONACYT, Mexico. We gratefully thank Audelia Alanís-Vega from INCMNSZ for availability of samples. This work was financed by CONACYT, Mexico, grant CB-2010-153527.

\section{Funding}

This work was financed by CONACyT, Mexico grant CB-2010-153527. CONACyT did not intervene in design of the study, sample collection, experimentation, analysis, and interpretation of data, nor in the writing of the manuscript.

\section{Availability of data and materials}

The data sets supporting the conclusions of this article are deposited in Gene Expression Omnibus (GEO), series record GSE73968 at http:// www.ncbi.nlm.nih.gov/geo/query/acc.cgi?acc=GSE73968

\section{Authors' contributions}

GO-G, Conception and design, experimental work, data collection, analysis and interpretation, manuscript writing. TA-GT, Experimental work, data collection, analysis and interpretation. FG-J, Experimental work, data collection, analysis and interpretation. II-R, Bioinformatics analysis of raw microarray data and bioinformatics guidance, critical review of the article, manuscript writing. CR-E, Bioinformatics analysis of raw microarray data and bioinformatics guidance, critical review of the article. LO, Conception and design, critical review of the article. IA-D, Conception and design, critical review of the article. JAV$P$, guidance in PCR by high-throughput gene expression, critical review of the article. JZ, Conception and design, critical review of the article. SP-P, Conception and design, patient recruitment, critical review of the article. EE. Conception and design, data analysis and interpretation, manuscript writing. All authors read and approved the final manuscript.

\section{Competing interests}

The authors declare that they have no competing interests.

\section{Consent for publication}

No personal data from participants are displayed in this work.

\section{Ethics approval and consent to participate}

This study was approved by the ethics review boards of Instituto Nacional de Enfermedades Respiratorias Ismael Cosío Villegas (B29-11) and Instituto Nacional de Ciencias Médicas y Nutrición Salvador Zubirán (1403). All patients signed written informed consent according with the Helsinki Protocol.

\section{Author details}

'Department of Research in Immunology, Instituto Nacional de Enfermedades Respiratorias Ismael Cosío Villegas, Calzada de Tlalpan 4502, Mexico City, Mexico. ${ }^{2}$ Computational Genomics Department, Instituto Nacional de Medicina Genómica, Periferico Sur 4809, Mexico City, Mexico. ${ }^{3}$ Laboratory of Immunogenomics and Metabolic Diseases, Instituto Nacional de Medicina Genómica, Periferico Sur 4809, Mexico City, Mexico.

${ }^{4}$ Department of Virology, Instituto Nacional de Enfermedades Respiratorias Ismael Cosío Villegas, Calzada de Tlalpan 4502, Mexico City, Mexico.

${ }^{5}$ Infectious Immunopathogenesis Laboratory, Department of Infectious Diseases, Instituto Nacional de Ciencias Médicas y Nutrición Salvador Zubirán, Avenida Vasco de Quiroga 15, Mexico City, Mexico.

Received: 11 June 2016 Accepted: 17 November 2016 Published online: 22 November 2016

\section{References}

1. Lu X, Li Z, Li Q, Jiao Y, Ji Y, Zhang H, et al. Preferential loss of gut-homing a4 37 CD4(+) T cells and their circulating functional subsets in acute HIV-1 infection. Cell Mol Immunol. 2015;13:776-84.

2. Lim SG, Condez A, Lee CA, Johnson MA, Elia C, Poulter LW. Loss of mucosal CD4 lymphocytes is an early feature of HIV infection. Clin Exp Immunol. 1993:92:448-54

3. Guadalupe M, Reay E, Sankaran S, Prindiville T, Flamm J, McNeil A, et al. Severe CD4+ T-cell depletion in gut lymphoid tissue during primary human immunodeficiency virus type 1 infection and substantial delay in restoration following highly active antiretroviral therapy. J Virol. 2003;77:11708-17.

4. Brenchley JM, Schacker TW, Ruff LE, Price DA, Taylor JH, Beilman GJ, et al. CD4+ T cell depletion during all stages of HIV disease occurs predominantly in the gastrointestinal tract. J Exp Med. 2004;200:749-59.

5. Picker LJ, Hagen SI, Lum R, Reed-Inderbitzin EF, Daly LM, Sylwester AW, et al. Insufficient production and tissue delivery of CD4+ memory T cells in rapidly progressive simian immunodeficiency virus infection. J Exp Med. 2004:200:1299-314.

6. Okoye A, Meier-Schellersheim M, Brenchley JM, Hagen SI, Walker JM, Rohankhedkar M, et al. Progressive CD4+ central memory T cell decline results in CD4+ effector memory insufficiency and overt disease in chronic SIV infection. J Exp Med. 2007:204:2171-85.

7. Mahnke YD, Brodie TM, Sallusto F, Roederer M, Lugli E. The who's who of Tcell differentiation: human memory T-cell subsets. Eur J Immunol. 2013:43: 2797-809. 
8. Appay V, van Lier RAW, Sallusto F, Roederer M. Phenotype and function of human T lymphocyte subsets: consensus and issues. Cytom Part J Int Soc Anal Cytol. 2008;73:975-83.

9. Okoye AA, Rohankhedkar M, Abana C, Pattenn A, Reyes M, Pexton C, et al. Naive $T$ cells are dispensable for memory CD4+ T cell homeostasis in progressive simian immunodeficiency virus infection. J Exp Med. 2012;209:641-51.

10. Rivino L, Messi M, Jarrossay D, Lanzavecchia A, Sallusto F, Geginat J. Chemokine receptor expression identifies Pre-T helper (Th)1, Pre-Th2, and nonpolarized cells among human CD4+ central memory T cells. J Exp Med. 2004;200:725-35.

11. Wang A, Chandran S, Shah SA, Chiu Y, Paria BC, Aghamolla T, et al. The stoichiometric production of IL-2 and IFN- $\gamma$ mRNA defines memory T cells that can self-renew after adoptive transfer in humans. Sci Transl Med. 2012;4:149ra120.

12. Bai F, Tincati C, Merlini E, Pacioni C, Sinigaglia E, Carpani G, et al. Reduced central memory CD4+ T cells and increased t-cell activation characterise treatment-naive patients newly diagnosed at late stage of HIV infection. AIDS Res Treat. 2012;2012:314849.

13. Kovacs JA, Lempicki RA, Sidorov IA, Adelsberger JW, Herpin B, Metcalf JA, et al. Identification of dynamically distinct subpopulations of T lymphocytes that are differentially affected by HIV. J Exp Med. 2001;194:1731-41.

14. Feinberg MB, McCune JM, Miedema F, Moore JP, Schuitemaker H. HIV tropism and CD4+ T-cell depletion. Nat Med. 2002;8:537.

15. Grossman Z, Meier-Schellersheim M, Paul WE, Picker L. Pathogenesis of HIV infection: what the virus spares is as important as what it destroys. Nat Med. 2006;12:289-95

16. Alimonti JB, Ball TB, Fowke KR. Mechanisms of CD4+ T lymphocyte cell death in human immunodeficiency virus infection and AIDS. J Gen Virol. 2003:84:1649-61.

17. Anderson RW, Ascher MS, Sheppard HW. Direct HIV cytopathicity cannot account for CD4 decline in AIDS in the presence of homeostasis: a worstcase dynamic analysis. J Acquir Immune Defic Syndr Hum Retrovirol Off Publ Int Retrovirol Assoc. 1998;17:245-52.

18. Rodríguez B, Sethi AK, Cheruvu VK, Mackay W, Bosch RJ, Kitahata M, et al. Predictive value of plasma HIV RNA level on rate of CD4 T-cell decline in untreated HIV infection. JAMA J Am Med Assoc. 2006;296:1498-506.

19. Funk GA, Oxenius A, Fischer M, Opravil M, Joos B, Flepp M, et al. HIV replication elicits little cytopathic effects in vivo: analysis of surrogate markers for virus production, cytotoxic T cell response and infected cell death. J Med Virol. 2006;78:1141-6.

20. Taddeo B, Nickoloff BJ, Foreman KE. Caspase inhibitor blocks human immunodeficiency virus 1-induced T-cell death without enhancement of HIV-1 replication and dimethyl sulfoxide increases HIV-1 replication without influencing T-cell survival. Arch Pathol Lab Med. 2000;124:240-5.

21. Douek D. HIV disease progression: immune activation, microbes, and a leaky gut. Top HIV Med Publ Int AIDS Soc USA. 2007;15:114-7.

22. Hua W, Jiao Y, Zhang H, Zhang T, Chen D, Zhang Y, et al. Central memory CD4 cells are an early indicator of immune reconstitution in HIV/AIDS patients with anti-retroviral treatment. Immunol Invest. 2012;41:1-14.

23. Espinosa E, Ormsby CE, Reyes-Terán G, Asaad R, Sieg SF, Lederman MM. Dissociation of CD154 and cytokine expression patterns in CD38+ CD4+ memory T cells in chronic HIV-1 infection. J Acquir Immune Defic Syndr 1999. 2010;55:439-45.

24. Olvera-García G, Espinosa E, Sieg SF, Lederman MM. Cytomegalovirusspecific responses of CD38+ memory T cells are skewed towards IFN- $\gamma$ and dissociated from CD154 in HIV-1 infection. AIDS Lond Engl. 2014;28:311-6.

25. Irizarry RA, Hobbs B, Collin F, Beazer-Barclay YD, Antonellis KJ, Scherf U, et al. Exploration, normalization, and summaries of high density oligonucleotide array probe level data. Biostat Oxf Engl. 2003:4:249-64.

26. Gentleman RC, Carey VJ, Bates DM, Bolstad B, Dettling M, Dudoit S, et al. Bioconductor: open software development for computational biology and bioinformatics. Genome Biol. 2004;5:R80.

27. R Core Team, R: A Language and Environment for StatisticalComputing, R Foundation for Statistical Computing, Vienna, Austria, 2013 [Internet]. Available from: https://www.r-project.org/

28. Smyth GK. limma: Linear Models for Microarray Data. In: Gentleman R, Carey VJ, Huber W, Irizarry RA, Dudoit S, editors. Bioinforma. Comput. Biol. Solut. Using R Bioconductor [Internet]. Springer New York; 2005 [cited 2014 Jul 1]. p. 397-420. Available from: http://link.springer.com/chapter/10.1007/0-38729362-0_23.

29. Benjamini Y, Hochberg Y. Controlling the false discovery rate: a practical and powerful approach to multiple testing. J R Stat Soc Ser B Methodol. 1995:57:289-300.
30. Warnes GR, Bolker B, Bonebakke L, Gentleman R. gplots: Various R Programming Tools for Plotting Data [Internet]. 2015. Available from: http:// cran.r-project.org/web/packages/gplots/index.html.

31. Oliveros, J.C. Venny. An interactive tool for comparing lists with Venn's diagrams. [Internet]. Venny 202. 2007. Available from: http://bioinfogp.cnb. csic.es/tools/venny/index.html.

32. Huang DW, Sherman BT, Lempicki RA. Systematic and integrative analysis of large gene lists using DAVID bioinformatics resources. Nat Protoc. 2009:4:44-57.

33. Huang DW, Sherman BT, Lempicki RA. Bioinformatics enrichment tools: paths toward the comprehensive functional analysis of large gene lists. Nucleic Acids Res. 2009;37:1-13.

34. Subramanian A, Tamayo P, Mootha VK, Mukherjee S, Ebert BL, Gillette MA, et al. Gene set enrichment analysis: a knowledge-based approach for interpreting genome-wide expression profiles. Proc Natl Acad Sci U S A 2005;102:15545-50.

35. Krämer A, Green J, Pollard J, Tugendreich S. Causal analysis approaches in Ingenuity Pathway Analysis. Bioinforma Oxf Engl. 2014;30:523-30.

36. Vega-Sanchez R, Arenas-Hernandez M, Vazquez-Perez JA, Moreno-Valencia Y, Gomez-Lopez N. Evaluation of reference genes for expression studies in leukocytes from term human pregnancy. Placenta. 2015:36:240-5.

37. Vandesompele J, De Preter K, Pattyn F, Poppe B, Van Roy N, De Paepe A, et al. Accurate normalization of real-time quantitative RT-PCR data by geometric averaging of multiple internal control genes. Genome Biol. 2002; 3:RESEARCH0034.

38. Hadley Wickham. Reshaping Data with the reshape Package - paper. J Stat Softw. [Internet]. 2007;21. Available from: http://www.jstatsoft.org/ v21/i12/paper.

39. Team RC, Wuertz D, Setz T, Chalabi Y. fBasics: Rmetrics - Markets and Basic Statistics [Internet]. 2014 [cited 2015 Jul 31]. Available from: https://cran.rproject.org/web/packages/fBasics/index.html.

40. Willinger T, Freeman T, Hasegawa H, McMichael AJ, Callan MFC. Molecular signatures distinguish human central memory from effector memory CD8 T cell subsets. J Immunol Baltim Md 1950. 2005;175:5895-903.

41. Riou C, Yassine-Diab B, Van Grevenynghe J, Somogyi R, Greller LD, Gagnon $\mathrm{D}$, et al. Convergence of TCR and cytokine signaling leads to FOXO3a phosphorylation and drives the survival of CD4+ central memory T cells. J Exp Med. 2007;204:79-91.

42. Gattinoni L, Lugli E, Ji Y, Pos Z, Paulos CM, Quigley MF, et al. A human memory T cell subset with stem cell-like properties. Nat Med. 2011;17:1290-7.

43. Schwendemann J, Choi C, Schirrmacher V, Beckhove P. Dynamic differentiation of activated human peripheral blood CD8+ and CD4+ effector memory T cells. J Immunol Baltim Md 1950. 2005;175:1433-9.

44. Willinger T, Freeman T, Herbert M, Hasegawa H, McMichael AJ, Callan MFC. Human naive CD8 T cells down-regulate expression of the WNT pathway transcription factors lymphoid enhancer binding factor 1 and transcription factor 7 ( 1 cell factor-1) following antigen encounter in vitro and in vivo. J Immunol Baltim Md 1950. 2006;176:1439-46.

45. Babich A, Burkhardt JK. Coordinate control of cytoskeletal remodeling and calcium mobilization during T-cell activation. Immunol Rev. 2013;256:80-94.

46. Feng $X$, Wang $H$, Takata $H$, Day TJ, Willen J, Hu H. Transcription factor Foxp1 exerts essential cell-intrinsic regulation of the quiescence of naive $T$ cells. Nat Immunol. 2011:12:544-50.

47. Nagashima H, Okuyama $Y$, Asao A, Kawabe T, Yamaki S, Nakano H, et al. The adaptor TRAF5 limits the differentiation of inflammatory CD4+ T cells by antagonizing signaling via the receptor for IL-6. Nat Immunol. 2014;15:449-56.

48. Ogretmen B, Hannun YA. Biologically active sphingolipids in cancer pathogenesis and treatment. Nat Rev Cancer. 2004;4:604-16.

49. Knox JJ, Cosma GL, Betts MR, McLane LM. Characterization of T-bet and eomes in peripheral human immune cells. Front Immunol. 2014;5:217.

50. Crotty S, Johnston RJ, Schoenberger SP. Effectors and memories: BCl-6 and Blimp-1 in T and B lymphocyte differentiation. Nat Immunol. 2010; 11:114-20.

51. Haabeth OAW, Tveita AA, Fauskanger M, Schjesvold F, Lorvik KB, Hofgaard PO, et al. How do CD4(+) T cells detect and eliminate tumor cells that either lack or express MHC Class II molecules? Front Immunol. 2014;5:174.

52. Marshall NB, Swain SL. Cytotoxic CD4 T Cells in antiviral immunity. BioMed Res Int. 2011;2011:e954602.

53. Marcolino I, Przybylski GK, Koschella M, Schmidt CA, Voehringer D, Schlesier $M$, et al. Frequent expression of the natural killer cell receptor KLRG1 in 
human cord blood T cells: correlation with replicative history. Eur J Immunol. 2004;34:2672-80.

54. Henson SM, Akbar AN. KLRG1 - more than a marker for T cell senescence. AGE. 2009;31:285-91.

55. Heijink AM, Krajewska M, van Vugt MATM. The DNA damage response during mitosis. Mutat Res. 2013;750:45-55.

56. Topham CH, Taylor SS. Mitosis and apoptosis: how is the balance set? Curr Opin Cell Biol. 2013;25:780-5.

57. van Grevenynghe J, Procopio FA, He Z, Chomont N, Riou C, Zhang Y, et al. Transcription factor FOXO3a controls the persistence of memory CD4(+) T cells during HIV infection. Nat Med. 2008;14:266-74.

58. Sieg SF, Bazdar DA, Lederman MM. S-phase entry leads to cell death in circulating T cells from HIV-infected persons. J Leukoc Biol. 2008;83:1382-7.

59. Derks RA, Beaman KD. Regeneration and tolerance factor prevents bystander T-cell death associated with human immunodeficiency virus infection. Clin Diagn Lab Immunol. 2004;11:835-40.

60. Shmagel KV, Saidakova EV, Korolevskaya LB, Shmagel NG, Chereshnev VA, Anthony DD, et al. Influence of hepatitis C virus coinfection on $\mathrm{CD} 4^{+} \mathrm{T}$ cells of HIV-infected patients receiving HAART. AIDS Lond Engl. 2014;28:2381-8.

61. Honda R, Lowe ED, Dubinina E, Skamnaki V, Cook A, Brown NR, et al. The structure of cyclin E1/CDK2: implications for CDK2 activation and CDK2independent roles. EMBO J. 2005;24:452-63.

62. Lu X, Liu J, Legerski RJ. Cyclin E is stabilized in response to replication fork barriers leading to prolonged S phase arrest. J Biol Chem. 2009;284:35325-37.

63. Gerdes J, Lemke H, Baisch H, Wacker HH, Schwab U, Stein H. Cell cycle analysis of a cell proliferation-associated human nuclear antigen defined by the monoclonal antibody Ki-67. J Immunol Baltim Md 1950. 1984;133:1710-5.

64. Scholzen T, Gerdes J. The Ki-67 protein: from the known and the unknown. J Cell Physiol. 2000;182:311-22.

65. Presky DH, Yang H, Minetti L, Chua AO, Nabavi N, Wu CY, et al. A functional interleukin 12 receptor complex is composed of two beta-type cytokine receptor subunits. Proc Natl Acad Sci U S A. 1996;93:14002-7.

66. Jones ML, Young JM, Huang QR, Puls RL, Webber CA, Benson EM. Interleukin 12-augmented T cell proliferation of peripheral blood mononuclear cells from HIV-seropositive individuals is associated with interleukin 12 receptor beta 2 upregulation. AIDS Res Hum Retroviruses. 2003;19:283-92.

67. Liu C-M, Hsieh C-L, He Y-C, Lo S-J, Liang J-A, Hsieh T-F, et al. In vivo targeting of ADAM9 gene expression using lentivirus-delivered shRNA suppresses prostate cancer growth by regulating REG4 dependent cell cycle progression. PLoS One. 2013;8:e53795.

68. Deng $\mathrm{Q}$, Wang $\mathrm{Q}$, Zong $\mathrm{W}-\mathrm{Y}$, Zheng $\mathrm{D}-\mathrm{L}$, Wen $\mathrm{Y}-\mathrm{X}$, Wang $\mathrm{K}-\mathrm{S}$, et al. E2F8 contributes to human hepatocellular carcinoma via regulating cell proliferation. Cancer Res. 2010;70:782-91.

69. Delpuech O, Griffiths B, East P, Essafi A, Lam EW-F, Burgering B, et al. Induction of Mxi1-SR alpha by FOXO3a contributes to repression of Mycdependent gene expression. Mol Cell Biol. 2007;27:4917-30.

70. Chattopadhyay S, Bielinsky A-K. Human Mcm10 regulates the catalytic subunit of DNA polymerase-alpha and prevents DNA damage during replication. Mol Biol Cell. 2007;18:4085-95

71. Albagli O, Lantoine D, Quief S, Quignon F, Englert C, Kerckaert JP, et al. Overexpressed BCL6 (LAZ3) oncoprotein triggers apoptosis, delays $S$ phase progression and associates with replication foci. Oncogene. 1999;18:5063-75.

72. Ichii H, Sakamoto A, Arima M, Hatano M, Kuroda Y, Tokuhisa T. Bcl6 is essential for the generation of long-term memory CD4+ T cells. Int Immunol. 2007;19:427-33.

73. Basso K, Dalla-Favera R. BCL6: master regulator of the germinal center reaction and key oncogene in B cell lymphomagenesis. Adv Immunol. 2010;105:193-210.

74. Feijoo C, Hall-Jackson C, Wu R, Jenkins D, Leitch J, Gilbert DM, et al. Activation of mammalian Chk1 during DNA replication arrest a role for Chk1 in the intra-S phase checkpoint monitoring replication origin firing. J Cell Biol. 2001;154:913-24.

75. Maaser K, Borlak J. A genome-wide expression analysis identifies a network of EpCAM-induced cell cycle regulators. Br J Cancer. 2008;99:1635-43.

76. Gery S, Komatsu N, Baldjyan L, Yu A, Koo D, Koeffler HP. The circadian gene per1 plays an important role in cell growth and DNA damage control in human cancer cells. Mol Cell. 2006;22:375-82.

77. Patel NM, Nozaki S, Shortle NH, Bhat-Nakshatri P, Newton TR, Rice S, et al. Paclitaxel sensitivity of breast cancer cells with constitutively active NFkappaB is enhanced by lkappaBalpha super-repressor and parthenolide. Oncogene. 2000;19:4159-69.
78. Kousholt AN, Fugger K, Hoffmann S, Larsen BD, Menzel T, Sartori AA, et al. CtIP-dependent DNA resection is required for DNA damage checkpoint maintenance but not initiation. J Cell Biol. 2012;197:869-76.

79. Mountain V, Simerly C, Howard L, Ando A, Schatten G, Compton DA. The kinesin-related protein, HSET, opposes the activity of Eg5 and cross-links microtubules in the mammalian mitotic spindle. J Cell Biol. 1999;147:351-66.

80. Takahashi H, Komatsu N, Ibe M, Ishida-Yamamoto A, Hashimoto Y, lizuka H. Cystatin A suppresses ultraviolet B-induced apoptosis of keratinocytes. J Dermatol Sci. 2007;46:179-87.

81. Malathi K, Paranjape JM, Ganapathi R, Silverman RH. HPC1/RNASEL mediates apoptosis of prostate cancer cells treated with 2',5'-oligoadenylates, topoisomerase I inhibitors, and tumor necrosis factor-related apoptosisinducing ligand. Cancer Res. 2004;64:9144-51.

82. Ke N, Claassen G, Yu D-H, Albers A, Fan W, Tan P, et al. Nuclear hormone receptor NR4A2 is involved in cell transformation and apoptosis. Cancer Res. 2004;64:8208-12.

83. Ghazalpour A, Bennett B, Petyuk VA, Orozco L, Hagopian R, Mungrue IN, et al. Comparative analysis of proteome and transcriptome variation in mouse. PLoS Genet. 2011;7:e1001393.

84. Li JJ, Biggin MD. Gene expression. Statistics requantitates the central dogma. Science. 2015;347:1066-7.

85. Battle A, Khan Z, Wang SH, Mitrano A, Ford MJ, Pritchard JK, et al. Genomic variation. Impact of regulatory variation from RNA to protein. Science. 2015; 347:664-7.

86. Jovanovic M, Rooney MS, Mertins P, Przybylski D, Chevrier N, Satija R, et al. Immunogenetics. Dynamic profiling of the protein life cycle in response to pathogens. Science. 2015;347:1259038.

87. Li JJ, Bickel PJ, Biggin MD. System wide analyses have underestimated protein abundances and the importance of transcription in mammals. Peer J [lnternet]. 2014 [cited 2015 Mar 9];2. Available from: http://www.ncbi.nlm. nih.gov/pmc/articles/PMC3940484/.

88. Zhang X, Chang Li X, Xiao X, Sun R, Tian Z, Wei H. CD4(+)CD62L(+) central memory T cells can be converted to Foxp3(+) T cells. PLoS One. 2013;8: e77322.

89. Okoye AA, Picker LJ. CD4(+) T-cell depletion in HIV infection: mechanisms of immunological failure. Immunol Rev. 2013;254:54-64.

90. Potter SJ, Lacabaratz C, Lambotte O, Perez-Patrigeon S, Vingert B, Sinet M, et al. Preserved central memory and activated effector memory CD4+ T-cell subsets in human immunodeficiency virus controllers: an ANRS EP36 study. J Virol. 2007:81:13904-15.

91. Sallusto F, Lenig D, Förster R, Lipp M, Lanzavecchia A. Two subsets of memory T lymphocytes with distinct homing potentials and effector functions. Nature. 1999:401:708-12.

92. Graef P, Buchholz VR, Stemberger C, Flossdorf M, Henkel L, Schiemann M, et al. Serial transfer of single-cell-derived immunocompetence reveals stemness of CD8(+) central memory T cells. Immunity. 2014;41:116-26.

93. Szabo SJ, Kim ST, Costa GL, Zhang X, Fathman CG, Glimcher LH. A novel transcription factor, T-bet, directs Th1 lineage commitment. Cell. 2000;100: 655-69.

94. Wu JQ, Wang B, Saksena NK. Transitory viremic surges in a human immunodeficiency virus-positive elite controller can shift the cellular transcriptome profile: a word of caution for microarray studies. J Virol. 2008; 82:10326-7.

95. Panel on Antiretroviral Guidelines for Adults and Adolescents. Guidelines for the use of antiretroviral agents in HIV-1-infected adults and adolescents. Department of Health and Human Services. Available at http://aidsinfo.nih. gov/contentfiles/lvguidelines/AdultandAdolescentGL.pdf. Section Accessed 18 Nov 2016.

96. Clarke PR, Allan LA. Cell-cycle control in the face of damage-a matter of life or death. Trends Cell Biol. 2009;19:89-98.

97. Combadère B, Blanc C, Li T, Carcelain G, Delaugerre C, Calvez V, et al. CD4 + Ki67+ lymphocytes in HIV-infected patients are effector T cells accumulated in the G1 phase of the cell cycle. Eur J Immunol. 2000;30:3598-603.

98. Sousa AE, Carneiro J, Meier-Schellersheim M, Grossman Z, Victorino RM. CD4 T cell depletion is linked directly to immune activation in the pathogenesis of HIV-1 and HIV-2 but only indirectly to the viral load. J Immunol. 2002;169:3400-6.

99. Gordon SN, Cervasi B, Odorizzi P, Silverman R, Aberra F, Ginsberg G, et al. Disruption of intestinal CD4+ T cell homeostasis is a key marker of systemic CD4 + T cell activation in HIV-infected individuals. J Immunol. 2010;185:5169-79.

100. Wickman G, Julian L, Olson MF. How apoptotic cells aid in the removal of their own cold dead bodies. Cell Death Differ. 2012;19:735-42. 
101. Koning FA, Otto SA, Hazenberg MD, Dekker L, Prins M, Miedema F, et al. Low-level CD4+ T cell activation is associated with low susceptibility to HIV1 infection. J Immunol. 2005;175:6117-22.

102. Srinivasula S, Lempicki RA, Adelsberger JW, Huang C-Y, Roark J, Lee PI, et al. Differential effects of HIV viral load and CD4 count on proliferation of naive and memory CD4 and CD8 T lymphocytes. Blood. 2011;118:262-70.

103. Herbeuval J-P, Hardy AW, Boasso A, Anderson SA, Dolan MJ, Dy M, et al. Regulation of TNF-related apoptosis-inducing ligand on primary CD4+ T cells by HIV-1: role of type I IFN-producing plasmacytoid dendritic cells. Proc Natl Acad Sci U S A. 2005;102:13974-9.

104. Bousheri S, Burke C, Ssewanyana I, Harrigan R, Martin J, Hunt P, et al. Infection with different hiv subtypes is associated with CD4 activationassociated dysfunction and apoptosis. J Acquir Immune Defic Syndr 1999. 2009;52:548-52.

105. Sieg SF, Rodriguez B, Asaad R, Jiang W, Bazdar DA, Lederman MM. Peripheral S-phase T cells in HIV disease have a central memory phenotype and rarely have evidence of recent T cell receptor engagement. J Infect Dis. 2005;192:62-70.

106. Pitrak DL, Novak RM, Estes R, Tschampa J, Abaya CD, Martinson J, et al. Short communication: apoptosis pathways in HIV-1-infected patients before and after highly active antiretroviral therapy: relevance to immune recovery. AIDS Res Hum Retroviruses. 2015:31:208-16.

107. Miao EA, Rajan JV, Aderem A. Caspase-1-induced pyroptotic cell death. Immunol Rev. 2011;243:206-14.

108. Elliott Jl, Surprenant A, Marelli-Berg FM, Cooper JC, Cassady-Cain RL, Wooding $C$, et al. Membrane phosphatidylserine distribution as a non-apoptotic signalling mechanism in lymphocytes. Nat Cell Biol. 2005;7:808-16.

109. Segawa K, Suzuki J, Nagata S. Constitutive exposure of phosphatidylserine on viable cells. Proc Natl Acad Sci U S A. 2011;108:19246-51.

110. Fuchs $Y$, Steller H. Live to die another way: modes of programmed cell death and the signals emanating from dying cells. Nat Rev Mol Cell Biol. 2015;16:329-44.

111. Song J, Jiao Y, Zhang T, Zhang Y, Huang X, Li H, et al. Longitudinal changes in plasma Caspase- 1 and Caspase-3 during the first 2 years of HIV-1 infection in CD4Low and CD4High patient groups. PLoS One. 2015;10: e0121011.

112. Lozza L, Rivino L, Guarda G, Jarrossay D, Rinaldi A, Bertoni F, et al. The strength of $T$ cell stimulation determines IL-7 responsiveness, secondary expansion, and lineage commitment of primed human CD4 + IL-7Rhi T cells. Eur J Immunol. 2008;38:30-9.

113. Croker BA, O'Donnell JA, Gerlic M. Pyroptotic death storms and cytopenia. Curr Opin Immunol. 2014;26:128-37.

114. Doitsh G, Galloway NLK, Geng X, Yang Z, Monroe KM, Zepeda O, et al. Cell death by pyroptosis drives CD4 T-cell depletion in HIV-1 infection. Nature. 2014;505:509-14

115. Brenchley JM, Price DA, Schacker TW, Asher TE, Silvestri G, Rao S, et al. Microbial translocation is a cause of systemic immune activation in chronic HIV infection. Nat Med. 2006;12:1365-71.

116. Shive CL, Mudd JC, Funderburg NT, Sieg SF, Kyi B, Bazdar DA, et al. Inflammatory cytokines drive CD4+ T-cell cycling and impaired responsiveness to interleukin 7: implications for immune failure in HIV disease. J Infect Dis. 2014;210:619-29.

117. Ahmad R, Sindhu STA, Toma E, Morisset R, Ahmad A. Elevated levels of circulating interleukin-18 in human immunodeficiency virus-infected individuals: role of peripheral blood mononuclear cells and implications for AIDS pathogenesis. J Virol. 2002;76:12448-56.

\section{Submit your next manuscript to BioMed Central and we will help you at every step:}

- We accept pre-submission inquiries

- Our selector tool helps you to find the most relevant journal

- We provide round the clock customer support

- Convenient online submission

- Thorough peer review

- Inclusion in PubMed and all major indexing services

- Maximum visibility for your research

Submit your manuscript at www.biomedcentral.com/submit
Biomed Central 